\title{
Omọ Tí A Kò Kọ́: Globalization and Cultural Education among New Generation Nigerian Yorùbá
}

\author{
Michael O. Afolayan \\ M \& P Educational Consulting International \\ mafolayan@yahoo.com
}

\begin{abstract}
This essay critically explores the semantic, phonological and philosophical implications of the sound "kộ" (build) in the Yorùbá proverb-Omọ tí a kò kọ ni yóo gbé ilé tí a kọ tà (the child that is not taught will eventually sell the house that is built). I will read the concept behind the sound as a multi-layered, multi-semantic meta-philosophical building block which not only showcases a serious aspect of indigenous epistemology and serving as a note of caution on Yorùbá education and its sociology of filial responsibilities, but could also be deployed to interrogate the emerging youth culture of the new generation Nigerian Yorùbá in the age of globalization. The essay draws on the semantic and philosophical content of kọ to articulate the argument that investments on material possession are counterproductive and antithetic to investment on human capital, the epitome of which is investing on one's child/ ren. The essay concludes that the spirituality and permanency of the kọ of the child's mind is diagonally opposed to the superficiality and transience of the $k o ̣$ of the building, a mere structure with limited value.
\end{abstract}

Keywords: Youth culture, Human capital, Yorùbá youth, Globalization

1 The value the Yorùbá attach to an appropriate upbringing, especially in training a child, is expressed in the age-long poem, "Ọmọ Ni İgbẹ hìn Ọlà." The poem provides a repertoire of distinct characters expected of a child. They include the act that a child is igbẹ hì ọlà, the epitome (peak, manifestation, essence, end-product) of wealth, ará- relatives (true companion, close associates), and èye-dignity. Thus, the young ones must be raised to reinforce the house that is built. Manifestations of omọ tí a kò kọ have implications for cultural continuity because the child not raised properly will destroy the essence of familiness. The saying that b'ílé bá tòrò, ọmọ àlè ibẹ ni kò tíi dàgbà ("if there is peace in the family, it means the family bastard has yet to be grown") supports the salient belief. 
Each profession, intellectual or manual, deserves consideration, whether it requires painful physical effort or manual dexterity, wide knowledge or the patience of an ant. Ours, like that of the doctor, does not allow for any mistake. To warp a soul is as much a sacrilege as murder. Teachers - at kindergarten level, as at university level - form a noble army accomplishing daily feats, never praised, never decorated. An army forever on the move, forever vigilant. An army without drums, without gleaming uniforms. This army, thwarting traps and snares, everywhere plants the flag of knowledge and morality. How we loved this priesthood. . . How faithfully we serve our profession. How we spent ourselves in order to do honor ... In those children we set in motion waves that, breaking, carried away in their furl a bit of ourselves.

\section{Introduction: The Fool's Truth}

A joke is currently making the rounds on social media. It tells of a new Japanese invention, a machine designed to catch thieves. It was tested in malls around the globe. Countries noted in the story include the United States, the United Kingdom, Spain, Ghana, Uganda, and Nigeria. The result was swift and the outcomes came with unfathomable ramifications. Within a short span of field-testing, it caught several thieves in all those countries. Twenty thieves were caught within thirty minutes of testing in the United States; five hundred in thirty minutes of testing in the United Kingdom; and twenty-five in Spain within the same time frame. Moving to Africa now, a ten-minute testing in Ghana caught 6,000 thieves; a whooping 20,000 thieves were caught within seven minutes of Ugandan testing; but when the same test was conducted in Nigeria, the machine itself was stolen within five minutes of being set up to catch thieves. Interesting!

The good news is that this was a joke; but the stinker is that jokes do problematize social realities. In classical works, it was the jesters that revealed the most crucial social predicaments that could not be prosecuted in the court of public opinions, and they gave the most politically non-correct news in the Shakespearean plays. It was a part of the poetic license designed to break through the walls that shielded the "sacred cows," the inordinately ambitious, and the corrupt powers of the time; that way, they, too, could have a taste of the sting of exposures to societal stigmas. Indeed, in Yorùbá history, we learned of the monarch, Oba Jáayin, who committed suicide when he learned of the imminent exposure of his ills by the town criers at the market square in Oyo, prompting the saying that $O$ ku deẹdẹ k'á gb'éwi d'Ákẹẹsán, l'Ọba Jáayin tẹ'ri gbaṣo ("shortly before the griots would make a poetic proclamation 
[of the monarch's ills] in the Akẹsán village square, Oba Jáayin committed suicide"). In essence, jokes and jesters had no fear declaring, "the emperor is naked" and the declaration could evoke lasting ramifications. The current parody is therefore taken seriously as an aspect of the data that exposes the social condition of the youth culture.

For whatever it is worth, in deconstructing the parody of the thief-catching machine, we find truth in certain facts: first, malls are a phenomenon of recent generations; secondly, it seems countercultural behaviors, including foolhardy, blatant stealing in the public square, are integral parts of the culture also of the new generations more than they are of the older ones; and thirdly, we are aware that Nigeria has been branded among the most corrupt nations of the world. In fact, according to the US News \& World Report of March 29, 2017 , in a survey of 21,000 global citizens, Nigeria was ranked the most corrupt, and it would be the second year in a row that the country occupies such a distasteful spot in the worldwide ranking. While there is no science to ascertain the survey's authenticity, suffice it to say that corruption has become endemic in Nigeria and has been institutionalized by rulers of the nation, most especially among the youth, a generation that has never known a time when corruption was not a part of the country's mode of operation. The fable, then, is an indictment of the youth culture, the critical mass of which falls in the collective paradigm of omo tí a kò kọ́ (the untaught child).

This paper focuses on this new generation of Yorùbá Nigerians. To remove ambiguity, we clarify the notion of "new" being those born after the 1970's. Our perspective is that with this group, there has been a complete shift in the paradigm of cultural education, the knowledge of, and attitude to, cultural literacy. ${ }^{2}$ This is not to suggest that generations predating the 1970 s were void of the presence of those in the paradigms of ábíkó and àkọoggbà. There is the gradual dying out of the most sacred of Yorùbá traditions, which have nothing to do with the youth culture (Abimbola 2016). But, the fact of the matter is that it never reached the threshold magnitude of the new generation in focus.

\section{The Semantic and the Phonological}

Omọ tí a kò kọ ni yó gbé ilé tí a kọ́ tà is a play on the phonological (tonemic), as well as the semantic complexity of the language. Yet, it is an attempt at showcasing a serious aspect of indigenous epistemology and serving as a note of caution on Yorùbá education and its sociology of filial responsibilities.

2 We separate the àbi kọo (the untaught child), from à kọoggbà, those suffering from what education psychologists call Oppositional Defiant Disorder. Either way, the individual is part of the post-1970 generations. 
The sound kó in Yorùbá, when brought into its various lexical categories, could mean 'to teach' or 'to train,' as in Lágbá já kọ Làkásègbè ní i iwé kíkà (X taught $\mathrm{Y}$ how to read). It could also mean 'to learn,' as in mo kọ i iwé ki kà ni ilé-iwé (I learned to read in school). The same could mean to build, as in bíríki la tí ó wu ki ó jẹ tí ó kọ i leé mi ko șe isẹe tí ó tẹ mi l'ọrun rárá (whoever the bricklayer was that built my house did not impress me one bit). Finally, as a split verb, it means 'to anchor' or 'to hang,' as in mo fi filà mi kọ ẹka igi orombó (I hanged my hat/cap on the branch of an orange tree); or mo gbé i bọn mi kọ orí igi orombó (I hanged my gun on the orange tree).

Observed closely, when each of those lexical items are combined, they culminate into a cultural value that fully defines indigenous education among the people. Much can be learned by closely observing the utterances of the Yorùbá people. Táíwò (2013) laments the fact that the depth of this native intelligence is yet to be explored. Verbal arts of the people demonstrate a sophisticated way of life with deep philosophical undertones. The art of being Yoruba comes loaded with spectrums of cultural nuances (Adéekó, 2017). As has been rightly observed (see Bangura 2015; Gbadegesin, 1991), there is a sense in which it is fair to say that traditional education among (and of) the Yorùbá, when utilized with other socio-cultural influences, including the Western, the Oriental and others, is sufficient to serve the people and provide adequate social and intellectual development for the people. This is because the inner reflection of the people of Africa often transfers into their outer perception of the world (Anyanwu and Ruch 1981), and in Verger's descriptive notation, "in a cultural universe established through oral traditions, where the values are different from those of a civilization based on written documents" (1995), there is value added to meanings of words. Take the multi-layered, multi-semantic concept $k o ́$ as an example; it is a meta-philosophical building block (with no pun intended). This is because for the Yorùbá, the totality of the life experiences of an individual is an unbreakable continuum that includes teaching, being taught, learning, building, being built, and anchoring one's self in the supra-sociological school of life. In this school, therefore, knowledge is taught, learned, built, and anchored on the human mind. This is a culturally choreographed social cycle that makes an individual whole and explains why the Yorùbá would always say that a child left untaught (ọmo tí a kò kọ́) or untrained-or who refuses to be taught or trained or be anchored on (and to) the tutelage of life or learned from, or built into, the school of life-would eventually sell off the house (a social and philosophical edifice) that is built. The homonymic significance of this combination takes us to a higher order of the philosophical thinking of the people. In essence, the word kọ tactfully articulates the fact that investments on material possessions are counterproductive and antithetic to investment on human capital, the epitome of which 
is investing on one's child or children. There is a play on the spiritual as well as the secular here. The spirituality and permanency of the kọ of the child's mind is diagonally opposed to the superficiality and transience of the kó of the building, a mere structure with limited value.

The Yorùbá recognize àbiikọ́ (omọ tí a kò kọ́-an untrained child) as opposed to àkọoggbà (omọ tí a kọ́ tí ko gbà-a child that refuses to be taught or trained). Furthermore, they believe that training the child does not guarantee the child will be receptive to the training. It is for this that the concept of àkọoggbà comes up. Ákọoggbà is the child that is hard of hearing, or a child that refuses to be taught or to learn. Warnings abound on the outcomes of such deliberate disobedience. A case in point is in the famous Yorùbá cosmology well documented in Abimbola (1975) on the birthing of the Ifá divination system. At the annual family jamboree, the last of the eight children of Orúnmilà, called Olowo, created a dramatic commotion when he refused to recognize the filial and royal supremacy of their father. This prompted the latter to trash the son's diadem and withdraw himself into a world unknown. Olowo broke the father's heart and broke the cause of humanity, bringing about a curse on mankind and utter destruction to the ecosystem. The myth of Olowo seems to be the primordial archetype of the majority new generation Yorùbá and the possible consequence of a rebellion against cultural education.

\section{Transference of Cultural Education as Foundation for Ethnic/ Nation Building}

Conventional wisdom is clear on the fact that the race of life, as mirrored by the one on the track, is lost or won in the exchange of the baton. The sociological reality is that the continuous survival of a culture is predicated on the successful passing of that culture from one generation to another. If the baton drops or is poorly exchanged, the race is bound to flop and fail. Likewise, cultural transmission presupposes a dynamic process in which one generation flawlessly passes the cultural nuances to members of a newer one. Passing my father's torch is the title of the memoir of Kalu Agbaa. The details of the author's narratives demonstrate his belief in the wholesale cultural impartation associated with his connection to his father. It then behooves him to pass the same to his children and in spite of the tragedies that permeated the family's diaspora sojourn; the author is determined to pass the sacred torch to posterity. Nothing could be more appropriate than this construct when engaged in the discourse on cross-generational transmission of culture. Culture is all the learned and expected ways of life of a people. It has to be learned in order to be known. The notion of the parent as the teacher, first teacher, is a 
universally accepted notion. It is not a metaphor; it is a natural reality. This is an area of failure among the Yorùbá of the current age.

\section{Globalization, Small World, and the Conflicts of False Globalization}

Globalization is a great asset. It is an integral part of the development of the modern world culture. Indeed, with the modern-day technology the world has become the much clichéd "global village." While the traditional Yorùbá worldview is always embracing of globalization, as in its b'ómodé ò bá d'óko

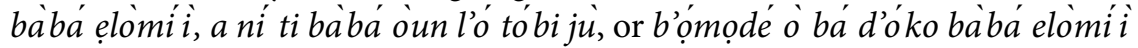
ri, a ni ko s'óko bảbá eni tó tóbi tó ti baba oun, ("when a child has not been to the farmland of other people's father, he thinks his father's is the largest"). Yet, the Yoruba culture is also almost always apprehensive, sometimes cynical, if not altogether leery, of globalization This is why in the context of the people's rhetoric, we hear sayings like bọộ dè ò dùn, bi ìgbé ni lú rí "“if the home is not set in order, life outside the home amounts to nothing" - like "shit"); k'o síbi t'o da'bí ile l'eye n' ké ("'nothing like home' is the song of the bird"); boọkọ ro'kun, bo roọsà, á wáa f'ori f'élébuiuté ("if the ships travels to the seas and across the lagoons, it must always return to its harbor"); b'ógiri ò lanu, alángbá ò lè ráye wọ’bẹ ("without a crack in the wall, the lizard cannot gain entrance into it"), and many more. The metaphors of seas, lagoons, outside the home, the lizard, and "the farmland of other people's father," etc., are indicative of the globe and the wide array of opportunities for exploring its vastness and the need to be apprehensive of its opportunities.

For modern-day Yorùbá society, the age of globalization has diminished the strength of localization, and consequently, the deliberate quest for the much-needed indigenous knowledge base is under serious assault. Anything but the indigenous is the preference for the neocolonial mind of the modern-day Yorùbá Nigerians. The public performance of a Yorùbá artist underscores this point. In the interesting parody, the protagonist, a father, sings and makes a supplication to be blessed with a beautiful wife and multiple children, seventeen in number, all of whom he hopes would live in a variety of nations around the world. His wish is that this "blessing" would turn him into a commonwealth father, an influential person around the globe. The problem was that conspicuously missing among his nations of choice for this father is Nigeria, the home base of the Yorùbá society, where one would expect that his offspring would be immersed in the needed cultural literacy that would have perpetuated him and posterity would grant him even a better passport to influence his world. He has no doubt failed the test of empowerment, because the global has the tendency to disempower the local. Unfortunately, one 
cannot be empowered if one is unable to "name one's world," as Paulo Freire has long posited (1989; 2006; Freire and Antonio 1989).

\section{The Vicious Cycle of Culpability}

Fairly, though, the blame (or the source of the problem) cannot rest solely on the members of the generation in focus here, as they may also be perceived in a sense as victims of the situation in which they find themselves. The blame could partially be on the parents as they are the first natural teachers who should lay the foundation on which to build the children's cultural education and indigenous knowledge. They should be among the "noble army" that "faithfully serves (its) profession." They are failing in that responsibility, and therein lies the problem. Case in point: in a recent study sponsored by the United Nations Children's Fund (UNICEF) on girls' education, this author engaged in a dialogue with a preschool Yorùbá child at a gathering but the mother aborted the effort by quickly interjecting and apologizing that the child did not speak Yorùbá and that I should not try to speak Yorùbá to her. When asked what language the child understood, the mother declared with pride and enthusiasm that the child only spoke the English language and that I should interview her in English. The tragic irony was that the child neither spoke the English language with any degree of proficiency nor did she know how to speak "her" mother tongue. Similar but not identical, just about one month earlier, in March 2017, to be specific, I sat next to a young mother at a church event in Ago Are, Oyo North, Nigeria (my emphasis on Oyo North is because of its deep Yorùbáness). The mother must have been in her thirties and her baby who sat between both of us was about three years of age. I eavesdropped on the mother's conversations with the little boy. They were all in English. Again, ironically, the mother's proficiency in the English language was itself quite low. The responses of the child also showed he did not understand much of what the mother was saying. In other words, neither the child nor the mother spoke English well. That, in my mind, has created a new level of dilemmas. If the mother who is teaching the child to speak English does not know how to speak the language herself, what should we expect of the child who is the primary recipient of the less standard version of the English language? In the words of Awoniyi, such new Yorùbá children are members of two worlds, and citizens of none. Such children would fit the model of what the Yorùbá call àgbọoggbọtán ègùn, ijà nií dáá'lè ("half-baked knowledge [of a language/culture, etc] that only gets one in trouble"). Shall we justifiably blame the child's poor performance in knowledge acquisition down the road? The foundation is already in decay; we cannot blame the instability on the rooftop. It is the age-long aphorism of the crooked top. 
Yet, there is a limit to how much blame goes on the parents as well. Like the proverbial "comfortable tripod that supports the cooking pot," John Dewey's triangle places the child at the center in which the government, the home and other members in the community surround and sustain the child. In that continuum, a dysfunctional government is as precarious to the child, just as an unstable family. Indeed, it is a known fact that the chances of the dysfunctionality of families in society are higher under an epileptic government than if they were under a stable one (Wardle, 2000). In other words, a dysfunctional government makes parents less purposeful in discharging their filial responsibilities as well. In a not-too-distant past, for example, a school system, sponsored by the then government of Western Nigerian, used to be readily available to assist parents in providing material needs for the smooth schooling of children. For the new generation, however, such support has fallen apart. In the era of ilé-iwé Awolowo (Awolowo's schools), the government was committed to the quality education of the Yorùbá child, making the work of the parent as well as that of the teacher easier. Because of the lack of that important support today, both parents and teachers are ill equipped to help children. In a new age where teacher salaries are held unpaid for months at a time, and up to one year in some instances, the teacher's morale has become non-existent. Education, which is supposed to be provided at home and supported at school, has miserably failed to be given either at home or at school. Besides, some of the parents also have no clue as to the seriousness of their inadequacies and the endemic nature of the problem the new generation they are raising is facing. This is because even many of these parents themselves have rejected, forgotten and/or abandoned, or are abysmally ignorant of the cultural education and its attending values. Fair enough, they can consequently not give what they do not seem to have. Having said that, and as to be discussed momentarily, we cannot ignore some efforts in some quarters of the political theater.

Take for example, Ọgbẹni Rauf Arẹgbẹ́sọlá, the current governor in İpínlẹ Omọluábí, Ộșun State, who is said to be making great strides in education by building new schools in every local government area to replace the old-fashioned and dilapidated ones, whose construction dates back to the 1950s or earlier. He has also been supplying new modern-day Coaster school buses, and experimenting with free mid-day meals for primary school children in the state. These are ostensibly the governor's flagship achievements together with the mega-road project known as ọna-baba-ọna ("father of all roads"). But while we applaud the unprecedented efforts of one of the best governors, what do we make of these so-called populist achievements when Ọṣun State employees and pensioners have not been paid their salaries in several months? Even as we could place the governor's physical development as nuli secondus, 
we cannot justifiably see it as empowering or advancing parents, students, and the greater cause of education in the state. The proverbial elephant projects can bring the elephant to the limelight of fame, but the grass below the elephant must surely suffer.

There exists the dangerous trajectory of the new generation Nigerians, which has often drifted towards anything foreign. The government and the larger corporations carry the heavy load of the blame but the bane is on the youth. Take sports for example: today, it is common practice among the average youth on the streets of Nigeria, most especially in the southwest, to spend their hard-earned money to bet on soccer games played by European championship teams. Indeed, there has been a variety of news of young Nigerians literally fighting to death in rooting for their favorite European teams.

The role of the government in perpetuating this anti-nationalistic trend and false globalization is palpable. Again, take another sports example; the government of Nigeria would rather travel to Europe, Asia, and South America to recruit coaches who would be paid several times more than an average Nigerian coach, although with far less of the needed practical experience at the game. Business organizations that use the game of soccer to promote their products do the same. In promoting its beverage, Milo, for example, the Milo Corporation in Nigeria currently features a well-publicized billboard commercial that is distributed in large sizes all around the major cities of the southwestern Nigeria. In this commercial is the image of two children playing soccer under the watchful eye of an incredible giant adult. For the logical mind, the first problem in this image is that the adult is one Drogba, a soccer player from another West African country with his name boldly printed to announce the hero that an average Nigerian child should dream of growing up to become. There is an immediate observable anomaly in this construct, philosophically and psychologically. The first question the inquisitive and rational mind would ask would be where are the super soccer heroes of Nigeria, hundreds, if not thousands, in number scattered around the world and across history as far back as 1950s Nigeria? Why would the choice of a player from another African country be made over that of a Nigerian? Is there not a subliminal message to the Yorùbá youth that any country but Nigeria, any hero but Nigerian would be higher on a scale of preference? Would the nation where Drogba comes from proudly display a Nigerian player, say, Jay Jay Okocha, the same way Nigeria has displayed Drogba as its own publicized hero? Is this globalization or an inferiority complex? Thirty Nigerian youths were recently electrocuted accidentally while watching two European soccer teams play. Would the same youths be so embracing of the Nigerian soccer teams, some of which are much better than many of those of Europe? Should we not rightly argue that globalization has gradually driven aspects of our 
local, indigenous culture into near extinction and confused the youth into disbelieving the cliché "there is no place like home"?

\section{A Departure from the Conscience of Shame and Guilt}

In a recent private conversation with a prominent Nigerian, we touched on what seems to be the problem with Nigeria and Nigerians of the current generation. It all lies on the absence of two values that the previous generations held in high esteem-guilt and shame. Elsewhere, I analyzed the Yorùbá notion of omọlúwàbí (Afolayan and Afolayan 2001; Afolayan and Wass 1995), and of character (Afolayan 2013). The Yorùbá believe that among the essentials of human existence is the virtue of iwà (poorly translated in the English language as "character"). It actually connotes the fact of being, the essence of humanity, and of life, etc. The sacred verses of the Ifá literary corpus speak to the salience of this virtue in Ifá literature (Abimbola, 1975, 1976, 1977). In addition to the absence of shame and guilt, one critical missing link between the old and the new generation is the absence of this sacred character of omolúwàbí, a special virtue that sets individuals aside as gentlemen or respectable ladies.

We digress to borrow one example that exemplifies the omọlúwàbí disposition in the 1970s at the University of Ife (present day Obafemi Awolowo University). At the university campus, there were several private newspaper vendors who came from town. They would haul bales of newspapers and magazines to the campus early in the morning every day, and place them on the open field in strategic places. Anyone who had the money (staff or students) and was interested in keeping the newspapers or magazines would pick up whichever they wanted, drop off the money on the open grass, and walk away with their newspapers and/or magazines. The vast majority never had any interest in keeping the newspapers or magazines or had no money to purchase them. Such individuals would congregate around the newspaper and read from page to page. When done, they folded the newspapers and put them back where they found them or sometimes passed them to another "free reader," as the bystander was called. It was quite impressive that the money, usually in coins, would be scattered all around the newspaper area. Rain or shine, the money would be there, just like it was in the village. The following day, the vendors would come back and pick up the coins. It never crossed anybody's mind to steal even a penny or take away the newspapers without paying for them. Those were the eras of innocence and today one cherishes such memories with nostalgia because the new generation never knew such culture ever existed. Theft is so endemic in the country today that even before anyone builds a house, they must first find money to build a fence around the 
property, which in some cases would be taller than the house being built! ${ }^{3}$ Understandable, though; after all, much of the money for the house is from a questionable source, making one to muse on the classical adage that "a house built on the strength of the spittle, would be brought down under the sprinkling drops of mere dew."

Attitudes to cultural education are empirical evidence of a lack of seriousness on the part of the new generation in embracing cultural literacy. Among this group are those who, for lack of shame and guilt, have no problem displaying Bachelor's or Master's degree certificates and diplomas that they have purchased, knowing full well they would soon be found wanting when put to the test and would be unable to pass tests meant for elementary school students. This is what happens when a supposed university graduate does not know how to spell the word "graduate," or cannot distinguish between the word "vacant" and "vacancy" while looking around for a job. Apparently, some in the group have hired individuals to sit for qualifying examinations for them; that way, they too would have a passing certificate. There is the scandalous assumption that when you have a certificate, you are sure to obtain a job. Since many of their television idols, politicians, television evangelists, and those commanding a great deal of money in society also obtained their certificates through similar means, there is no shame or guilt accruing from their indulgence or ambition to be engaged in such malpractice. This is a major crisis of an epidemic proportion, a phenomenon that has reached the threshold level in the tolerable absence of civility. It is no doubt, a violation of the norms and values the Yoruba society upholds.

\section{What Is To Be Done?}

The logical inquiry, then, is how this situation can be remedied. Even though we recognize the fact that this problem would require a major makeover, we have come up with a few "cosmetic" proposals that might help to launch the effort at addressing the problem.

I. Acknowledgement of the problem and its enormity. Acknowledging that the embrace of the knowledge of the Yorùbá culture, language, and essential ways of life of the people are endangered among the new generation individuals is the first step toward forging a lasting solution to the problem. The dangerous trajectory is palpably observable even on the street. For example, the tragic story is often told of a Yorùbá family domiciled overseas. In a freak accident, both the mother and father died. The three children were minors and the authorities had to intervene. When asked where they came from, the

3 Taken from the final draft of the manuscript of the Part 2 of my memoir, From Yale to Jail. 
children could only indicate having come from Africa. And although their first names and family names were Yorùbá, they had no idea what the word Yorùbá actually meant, let alone knowing the cultural artifacts that accompanied it. Thus, it is important to see the endemic propensity of this problem and the need to forge a lasting solution to it.

II. Decolonizing the mind. Ngũgĩs (1986) notion of decolonizing the mind is relevant to finding a solution to the new generation Yorùbá problem. This is a model that advocates a deliberate cleansing of the mind from the toxicity of the foreign embrace at the expense of cuddling the indigenous. This is applicable for the Yorùbá of all generations. The days of yore when members of all generations were proud of their Yorùbá cultural heritage are long gone. Songs in school and on the streets celebrated the richness of the culture. Such a model of education should be inculcated into the hearts of the members of the new generation Yorùbá, who may in turn rub such on their children.

III. Heavily investing on the future. While the fast-growing members of the current generation should not be ignored, strict attention should be paid to future generations. The critical mass of the current generation is like the proverbial dry fish, which is difficult to bend without being broken into smattering. For the few bendable ones, there is the possibility of benefitting at the bare minimum from the tutelage of elders in formal vocational settings. The energy of real resolution, however, should be exerted upon and directed at future generations. For the future generation, relentlessness and intentionality on the part of the older generation in cultural impartations are critical if the panacea efforts were to be effective. The relentlessness is underscored because the level of moral decay in the younger generation is exponentially greater than the level of normalcy. Besides, the agents of decay are more present in society than the agents of construction and cultural education. Once asked why he would still perform for two days after he was shot in Jamaica, Bob Marley was quoted to have said, "the people, who were trying to make this world worse are not taking a day off. How can I?" (https://www.brainyquote.com/authors/ bob marley). This is the underlying principle for the veracious intensity for propagating Yorùbá cultural education. With creativity and ebullience, even the most sacred aspects of our culture, say, for example, Ifá, can be taught to the next generation (Oyelaran, 2016).

IV. Deliberate immersion into all cultural components: culture is learned. Language is an integral part of culture and therefore must be taught and learned in the process of building up the child, nurturing him or her, and launching the child into full adulthood. Unfortunately, today, parents are not playing the role of the first teacher that they should be for their children when it comes to the matter of cultural literacy. A casual observation of the current dynamic in society reveals that Yorùbá culture is veering away from that 
cultural mandate. The narrative that accompanies a "call for paper" by Toyin Falola underscores this fact when it notes that "today, many cultural anthropologists and linguists agree that not only are the other Yorùbá dialects endangered as one generation fails to pass on the linguistic knowledge and skills to the next generation, but also that the common Yorùbá language itself is witnessing drastic decline in usage."

V. Rigorous instruction and induction. Training the young ones and intimating them with the danger in resisting cultural education is pertinent to winning the race, which seems to be one against time. One way of doing this is integrating Yorùbá cultural literacy into materials being produced for school usage. A good example is the way Akinwumi Isola utilized quality space in his memoir in propagating the folktale tradition (àó). In addition to teaching this tradition to the literate community, he documents this critical component of Yorùbá verbal art. Moyo Okediji insisted on providing a fulllength lecture in Yorùbá at an international conference in the United States. This, in a way, propagates the seriousness of Yorùbá culture and encourages members of the future generation Yorùbá to see the language in a light of global relevance and acceptance.

VI. Even among those in the diaspora, the need to raise a new generation that is culturally literate and which embraces the values of Yorùbá is quite real. Two recent success stories demonstrate efforts some individuals are making in ensuring such a possibility. A single mother has successfully raised a son whom she gave birth to and raised in the United States. The five-year old son speaks Yorùbá as if he was born and bred in a Yorùbá village. He also speaks English with native fluency. ${ }^{5}$ In the cosmopolitan city of Chicago is a Yorùbá family that provides music at Nigerian gatherings. Their three boys were all born in the United States. However, the three young men play the talking drums as if trained by native drummers in Nigeria, but it was their father, a Yorùbá musician, who trained them, in Chicago. They even often display their dexterity by producing melodic traditional proverbs with the talking drums and they do so with the right tunes and succinct precision. ${ }^{6}$

The point we try to make in suggesting these remedies is that for the future of Yorùbá culture to be grounded and guaranteed, cultural education is

4 Falola (2017) in "Call for Paper" for a future conference. This proposal was shared by Falola in a proposed project.

5 On one of the weekly radio programs hosted by my wife and me, Voice of Reason (www.goldenfl365.com), we bring the young man and his mother on the air to teach Yorùbá words to listeners on a weekly basis.

6 This family has performed for our Yorùbá groups in the Midwestern part of the United States on several occasions and the family skills are in high demand across the Yorùbá diaspora in the Americas. 
not an option; it is a requirement for the Yorùbá child. It must start in early childhood and when that stage is missed, which is the case among some of the post-adolescent Yorùbá youths today, there must be a systematic, and concerted integrating it into existing routines. It may start in bits and pieces, but it must start firm. Small changes, after all, can lead to radical transformations.

\section{Works Cited}

Abimbola, Wande. Sixteen Great Poems of Ifá. Paris: UNESCO, 1975.

Abimbola, Wande. Ifa: An Exposition of Ifa Literary Corpus. Ibadan: Oxford University Press, 1976.

Abimbola, Wande. Awon oju odu mereerindinlogun. Ibadan: Oxford University Press, 1977.

Abimbola, Wande. "Continuity and change in the verbal, artistic, ritualistic and performance traditions of Ifa divination." In Ifa Divination, Knowledge, Power, and Performance, eds. Jacob K. Olupona and Rowland Abiodun, 32-42. Bloomington \& Indianapolis: Indiana University Press, 2016.

Adeeko, Adeleke. Arts of Being Yoruba: Divination, Allegory, Tragedy, Proverbs, Panegyric. Bloomington: Indiana University Press, 2017.

Afolayan, Michael O. and Wass, B. "Yoruba Headties." In Crowning Achievements: African Arts of Dressing the Head, eds. Mary Jo Arnoldi and C. M. Kreamer, 139-146. Los Angeles: University of California, 1995.

Afolayan, Michael O. and Afolayan, P. O. "Deconstructing Epistemology: The Indigenous Language of Discourse Relating to Education in Yoruba Language." In Understanding Yorùbá Life and Culture, eds. Nike Lawal, Matthew N. O. Sadiku and P. Ade Dopamu. New York: The African World Press, 2001,

Michael O. Afolayan. "Esu ma se mi, omo elomii ni o se: A religious principle for ethical living." In Esu: Yoruba God, Power, and the Imaginative Frontiers, ed. Toyin Falola, 301-314. Durham: Carolina Academic Press, 2013.

Anyanwu, K. C. and Ruch, E. A. African Philosophy: An Introduction. Rome: Catholic Book Agency, 1981.

Bangura, Abdulkarim. Toyin Falola and African Epistemologies. New York: Palgrave Macmillan, 2015.

Freire, Paulo and Antonio, F. (1989), Learning to question: A Pedagogy of Liberation. New York: Continuum, 1989.

Freire, Paulo. Pedagogy of the Oppressed, 30th Anniversary edition (New York: Continuum, 2006.

Gbadegesin, Segun. African Philosophy: Traditional Yoruba Philosophy and Contemporary African realities. New York: Peter Lang, 1991. 
Oyelaran, O. O. "Ifa, knowledge, performance, the scared, and the medium." In Ifa Divination, Knowledge, Power, and Performance, eds. Jacob K. Olupona and Rowland Abiodun, 50-65. Bloomington \& Indianapolis: Indiana University Press, 2016.

Taiwo, Olufemi. "Kin n'Ifa wi?: Philosophical issues in Ifa divination." In Ifa Divination, Knowledge, Power, and Performance, eds. Jacob K. Olupona and Rowland Abiodun, 100-116. Bloomington \& Indianapolis: Indiana University Press, 2016.

Thiong'o, Ngũgĩ wa. Decolonising the Mind: The Politics of Language in African Literature. London: James Currey, Nairobi: Heinemann; New Hampshire: Heinemann, 1986.

Verger, P. V. Ewé: The Use of Plants in Yoruba Society. Rio de Janeiro: Odebrecht, 1995.

Wardle, L. D. "Relationships between family and government." In California Western International Law Journal, 31 (1), 1-21, 2000. 